\title{
PENGARUH PROGRESSIVE MUSCLE RELAXATION (PMR) TERHADAP TINGKAT STRES PADA IBU-IBU PKK USIA DEWASA TENGAH DI DUSUN NGEGOT, SELOKATON, GONDANGREJO, KARANGANYAR
}

\author{
Lis Sarwi Hastuti \\ Poltekkes Kemenkes Surakarta Jurusan Okupasi Terapi
}

\begin{abstract}
Background: Middle adulthood (40-59 years) is a transition period from early adulthood to late adulthood (elderly) which is marked by several changes, including physical / biological, mental, cognitive changes. This change has the potential to cause stress. This study aims to determine whether there is an effect of the provision of Progressive Muscle Relaxation / Progressive Muscle Relaxation on Stress Levels in middle-aged adult mothers in Ngegot villages, Selokaton, Gondangrejo, Karanganyar. The sampling technique in this study is to use total sampling. The number of samples in this study amounted to 26 respondents. This research is a type of pre-experimental research with one group pre-test and post-test design methods. Methods: The data analysis method used was a paired sample t-test statistical test technique with the help of SPSS 17.0. Data normality test used is by Shapiro-Wilk. Results: From the results of the analysis of the research data the normality of the data obtained the significance value with Shapiro-Wilk in the pre-test of $0.388(p>0.005)$ and post test of 0.073 ( $p>$ 0.005). Significance Value of the Effect of Progressive Muscle Relaxation Against Stress in middle adult mothers in Ngegot, Selokaton, Gondangrejo, Karanganyar villages with paired sample t-test analysis $p=0.001$.Conclusion: The results of this study indicate that there is an effect of Progressive Muscle Relaxation on Stress Levels in middle adult mothers in Ngegot, Selokaton, Gondangrejo, Karanganyar hamlets.
\end{abstract}

Keywords : Progressive Muscle Relaxation, Stres, Middle adulthood

\section{PENDAHULUAN}

Masa dewasa tengah (40-59 th) merupakan masa transisi dari dewasa awal menuju dewasa akhir (lansia), yang ditandai oleh beberapa perubahan, antara lain fisik/biologis, mental, dan kognitif. Perubahan pada masa dewasa tengah ini merupakan penurunan/pemunduran. Perubahan yang terjadi dapat berdampak negatif berupa munculnya stress dan depresi (Hurlock, 2012). Menurut Safari (2011), kasus stres kerja di dunia pendidikan menunjukkan bahwa 30,27\% dari 80.000 guru mengalami stres kerja berat yang berarti jumlah guru yang mengalami stres kerja ada 24.000 orang. Dalam studi tersebut juga disimpulkan bahwa stres kerja menurunkan kinerja guru dengan cepat, semakin tinggi stres kerja yang dialami oleh guru maka kinerja dan produktivitas kerja semakin rendah. Stres merupakan suatu keadaan yang sudah tidak asing lagi bagi kalangan masyarakat di seluruh dunia. Setiap orang kemungkinan pernah mengalami stres dalam berbagai bentuk dan tingkatan. Pada saat seseorang mengalami stres, dapat ditemui gejala seperti sulit tidur, timbul rasa kuatir yang berlebih, sulit berkonsentrasi dan masih banyak gejala 
lainnya (Kisker, 1997). Teknik relaksasi otot progresif merupakan teknik relaksasi otot dalam yang tidak memerlukan imajinasi, ketekunan atau sugesti (Setyoadi \& Kusharyadi, 2011). Relaksasi otot progresif merupakan salah satu teknik mengurangi ketegangan otot dengan proses yang simpel dan sistematis dalam menegangkan sekelompok otot kemudian merilaksasikan kembali (Marks, 2011). Selain untuk menurunkan tingkat stres, relaksasi otot progresif juga bermanfaat untuk mengurangi kelelahan, kram otot serta nyeri leher dan punggung (Berstein, Borkovec \& Steven, 2000).

\section{METODE PENELITIAN}

Penelitian ini menggunakan desain penelitian pre-experiment design dengan tipe one group pre test-post test. Tingkat stres diukur dengan menggunakan instrumen PSS ( Perceived Stress Scale). Responden adalah ibu-ibu PKK (RT $01 \&$ 02) dengan usia dewasa tengah (40-59 tahun). Intervensi diberikan sebanyak 16 kali dengan durasi 30 menit/sesi.

Analisis data menggunakan analisis univariat dan bivariat. Analisis univariat digunakan untuk mengetahui gambaran karakteristik responden, sedangkan analisis bivariat digunakan untuk mengetahui tingkat pengaruh Relaksasi Otot Progresif terhadap tingkat stres pada ibu-ibu PKK usia dewasa tengah dimana jenis data termasuk data ordinal dan uji beda yang digunakan adalah uji paired sample t-test karena data berdistribusi normal.

\section{HASIL PENELITIAN \\ Karakteristik responden berdasarkan usia dan status pernikahan sebagai berikut :}

Tabel 1. Distribusi Frekuensi Sampel

\begin{tabular}{lcc}
\hline Karakteristik & $\begin{array}{c}\text { Frekuensi } \\
\text { (Jumlah } \\
\text { Responden) }\end{array}$ & $\begin{array}{c}\text { Persentase } \\
(\%)\end{array}$ \\
\hline Usia & & \\
\hline $40-49$ tahun & 10 & 38 \\
50-59 tahun & 16 & 62 \\
\hline Status Pernikahan & & \\
\hline Menikah & 24 & 92 \\
Belum Menikah & 2 & 8 \\
\hline
\end{tabular}

Tabel 2. Data Distribusi Frekuensi nilai PSS (Perceived Stress Scale) Sebelum dilakukan Relaksasi Otot Progresif.

\begin{tabular}{lcr}
\hline Tingkat Stres & $\begin{array}{c}\text { Frekuensi } \\
\text { (Jumlah } \\
\text { Responden) }\end{array}$ & $\begin{array}{c}\text { Presentase } \\
(\%)\end{array}$ \\
\hline 0-13 (stres ringan) & 1 & 3.85 \\
14-26 (stres sedang) & 25 & 96.15 \\
27-40 (stres berat) & 0 & 0 \\
\hline Total & $\mathbf{2 6}$ & $\mathbf{1 0 0}$ \\
\hline
\end{tabular}

Tabel 3. Data Distribusi Frekuensi Nilai PSS (Perceived Stress Scale) Sesudah dilakukan Relaksasi Otot Progresif.

\begin{tabular}{ccc}
\hline Tingkat Stres & $\begin{array}{c}\text { Frekuensi } \\
\text { (Jumlah } \\
\text { Responden) }\end{array}$ & $\begin{array}{c}\text { Presentase } \\
\mathbf{( \% )}\end{array}$ \\
\hline 0-13 (stres ringan) & 8 & 30,77 \\
14-26 (stres sedang) & 18 & 69,33 \\
27-40 (stres berat) & 26 & 100 \\
\hline
\end{tabular}

Tabel 4. Nilai Means PSS (Perceived Stress Scale) Sebelum dan Sesudah dilakukan Relaksasi Otot Progresif

\begin{tabular}{cc}
\hline $\begin{array}{c}\text { Means PSS } \\
\text { sebelum Intervensi }\end{array}$ & $\begin{array}{c}\text { Means PSS sesudah } \\
\text { Intervensi }\end{array}$ \\
\hline 18.15 & 15.24 \\
\hline
\end{tabular}

Tabel 5. Hasil Uji Normalitas Data Shapiro-Wilk Test

\begin{tabular}{lcc}
\hline Variabel & $\boldsymbol{p}$ & $\begin{array}{c}\text { Kriteria } \\
\text { Keterangan }\end{array}$ \\
\hline $\begin{array}{l}\text { Nilai PSS } \\
\text { sebelum intervensi }\end{array}$ & 0,388 & Normal \\
$\begin{array}{l}\text { Nilai PSS } \\
\text { setelah intervensi }\end{array}$ & 0,073 & Normal \\
\hline
\end{tabular}


Tabel 6. Hasil Analisis Paired Sample TTest

\begin{tabular}{lc}
\hline Variabel & p-value \\
\hline Nilai PSS sebelum dan sesudah & 0,001 \\
\hline
\end{tabular}

\section{PEMBAHASAN}

Berdasarkan tabel 6. dapat diketahui bahwa dengan uji hasil Analisis Paired Sample T-Test nilai stres sebelum dan sesudah pemberian relaksasi otot progresif didapatkan nilai $p=0,001$ yang berarti bahwa Ha diterima dengan makna ada pengaruh latihan relaksasi otot progresif terhadap tingkat stres pada ibu usia dewasa tengah di Dusun Ngegot, Selokaton, Gondangrejo, karanganyar

Hal ini selaras dengan penelitian yang dilakukan oleh Resti (2014), yang berjudul "teknik relaksasi otot progresif untuk menurunkan stres pada penderita asma" menjelaskan beberapa keuntungan yang diperoleh dari latihan relaksasi diantaranya relaksasi membuat seseorang lebih mampu menghindari reaksi yang berlebihan karena adanya stres. Relaksasi otot progresif ini diberikan kepada responden didasarkan atas gejala stres yang muncul pada responden seperti mudah sakit kepala, punggung terasa sakit, bahu dan leher terasa kaku, kurang bisa fokus dalam bekerja dan sakit perut. Hal ini seperti yang diuangkapkan oleh Handoko (2008), bahwa stres adalah suatu kondisi ketegangan yang mempengaruhi proses berpikir, emosi, dan kondisi seseorang, hasilnya stres yang terlalu berlebihan dapat mengancam kemampuan seseorang untuk menghadapi lingkungan dan pada akhirnya akan mengganggu pelaksanaan tugas-tugasnya.

Relaksasi merupakan salah satu teknik pengelolaan diri yang didasarkan pada cara kerja sistem saraf simpatis dan parasimpatis. Teknik relaksasi semakin sering dilakukan terbukti efektif mengurangi ketegangan dan kecemasan (Utami, 2002). Hal ini selaras dengan beberapa penelitian bahwa relaksasi otot progresif dapat menurunkan tingkat stres dengan melakukan beberapa kali intervensi (Chen, 2009; Yildrim, 2006). Relaksasi yang dilakukan secara kontinue dapat menurunkan stres yang dialami oleh seseorang. (Davis, Eshelman \& Mckay, 1995).

Relaksasi otot progresif merupakan teknik manajemen stres cukup sering digunakan untuk mereduksi stres. Relaksasi otot progresif adalah suatu keterampilan yang dapat dipelajari dan digunakan untuk mengurangi atau menghilangkan ketegangan dan mengalami rasa nyaman tanpa tergantung pada hal/subjek diluar dirinya. Relaksasi otot progresif ini digunakan untuk melawan rasa cemas, stres, atau tegang. Dengan menegangkan dan melemaskan beberapa kelompok otot dan membedakan sensasi tegang dan rileks, seseorang bisa menghilangkan kontraksi otot dan mengalami rasa rileks (Soewondo, 2009).

Chaplin (1975) menyebutkan bahwa relaksasi adalah kembalinya otot ke keadaan istirahat setelah kontraksi, atau suatu keadaan tegang yang rendah dengan tanpa adanya emosi yang kuat. Menurut Thantawy (1997) relaksasi adalah teknik mengatasi kekhawatiran atau kecemasan atau stres melalui pengendoran otot-otot dan syaraf, itu terjadi atau bersumber pada objek-objek tertentu. Relaksasi merupakan suatu kondisi istirahat pada aspek fisik dan mental manusia sementara aspek spirit tetap aktif bekerja. Dalam keadaan relaksasi seluruh tubuh dalam keadaan homeostatis atau dalam keadaan tenang tapi tidak tertidur, dan seluruh otot-otot 
dalam keadaan rileks dengan posisi tubuh yang nyaman.

Adapun hasil penelitian diatas tidak selaras dengan penelitian yang dilakukan oleh Ariyanto (2015), yang berjudul "Pengaruh relaksasi otot progresif terhadap tingkat stres pada anak remaja di lapas Blitar" didapatkan hasil bahwa pemberian relaksasi otot progresif tidak berpengaruh terhadap penurunan tingkat stres pada anak remaja di lapas Blitar. Relaksasi yang telah dilakukan pada remaja kemungkinan hanya memberikan pengaruh yang relatif kecil bagi penurunan stres pada remaja. Terdapat variabel lain yang kemungkinan memiliki pengaruh yang lebih besar menurunkan tingkat stres pada remaja. Salah satu variabel yang dimungkinkan adalah dukungan sosial bagi remaja.Remaja yang mengalami fase perkembangan sangat membutuhkan suport sosial baik dari keluarga, lingkungan maupun teman sebayanya (Monk, 2004).

Relaksasi yang dilakukan secara kontinue dapat menurunkan stres yang dialami oleh seeorang.Manfaat dari relaksasi otot progresif ini dapat dirasakan apabila dilakukan dengan prosedur yang benar dan dilakukan selama satu atau dua minggu dan dilakukan selama 2 kali 15 menit setiap harinya (Davis, Eshelman \& Mckay, 1995).

Beberapa hal yang mendukung karakteristik responden diantaranya adalah bahwa seluruh responden adalah ibu-ibu kelompok usia dewasa tengah, dimana wanita memilii kecenderungan mengalami stress lebih besar. hal ini selaras dengan penelitian yang dilakukan oleh Akif (2007), yang berjudul stres kerja guru di Kecamatan Bantul Yogyakarta menunjukkan bahwa 65\% guru di Kecamatan Bantul mengalami stres kerja yang terdiri dari $45 \%$ guru perempuan dan $20 \%$ guru laki-laki. Bagi perempuan yang tidak dapat mencapai keseimbangan keluarga dan pekerjaan akan muncul masalah konflik yang berlangsung terusmenerus akan berdampak pada kelelahan fisik dan mental (Burke, 1994;Burke \& Greenglass, 2001; Kossek \& Ozeki,1999). Perempuan menikah lebih banyak mengalami konflik antara keluarga dan pekerjaan, dibandingkan dengan perempuan lajang, hal ini dapat menyebabkan stres khususnya bagi perempuan yang bekerja (Greenhaus \& Beutell, 1985). Perempuan menikah yang bekerja menghadapi lebih banyak persoalan terkait dengan peran yang dihadapi, yaitu sebagai istri, ibu, pengurus rumah tangga dan seorang pekerja (Ahmad, 1995). Menurut Hawari (2013), stres dapat berasal dari beban berlebih dan beban berlebih itu dapat berasal dari lingkungannya yang kemudian disebut sebagai stresor psikososial. Salah satu stressor psikososial adalah lingkungan hidup, hukum, faktor keluarga dan trauma.

\section{KESIMPULAN DAN SARAN}

Hasil penelitian dapat dapat disimpulkan bahwa ada pengaruh pemberian relaksasi otot progresif terhadap tingkat stres ibu usia dewasa tengah di Dusun Ngegot, Selokaton, Gondangrejo, Karanganyar, dengan nilai signifikansi $p=0,001$.

Pengaruh pemberian relaksasi otot progresif terhadap tingkat stres dapat diketahui dengan membandingkan nilai PSS(Perceived Stres Scale) responden sebelum dan sesudah diberikan latihan. Nilai rata-rata sebelum intervensi adalah 18,15 dan setelah intervensi nilai rata-rata sebesar 15,24. 


\section{DAFTAR RUJUKAN}

Ahmad, A.1995. Role conflict and coping behavior of working women. Pertanika JSocial, Journal of Science and Humaniora. Vol 3.

Ariyanto, E. A., 2015. Pengaruh Relaksasi Otot Progresif TerhadapTingkat Stres pada Remaja di Lapas Anak Blitar. Jurnal Psikologi Indonesia. Vol. 4.

Burke, R. J. 1994. Stressful events, workfamily conflict, coping, psychologica burnout and wellbeing among police officers. Journal of Psychological Reports. Vol 75.

Burke, R. J., \& Greenglass, E. R. (2001). Hospital restructuring, work-family conflict and burnout among nursing staff. Journal of Psychology and Health. Vol 16.

Chaplin, J.P. 1975. A dictionary of psychology. New York : A Laurel

\section{Edition.}

Davis, M., Eshelman, R.E., \& McKay.M (2015). Panduan relaksasi dan reduksi stres edisi III. Jakarta: EKG.

Kisker, G.W 1997. The disorganized personality: Thirt edition.

McGraw-Hill:Kogakusha,LTD.

Gibson,1996. Organisasi dan manajemen (Terjemah: Djarkasih, Edisi

Keempat). Jakarta: Erlangga.

Greenhaus, J. H., \&Beutell, N. J. (1985). Sources of conflict between wosrk and family roles. Academy of Management Review. Vol 10.

Handoko, T. H.2008. Mangement personalia. Yogyakarta: BPFE Yogyakarta.

Hawari, D. 2013. Manajemen stres, cemas dan depresi. Jakarta : KFUI

Hurlock, Elizabeth B. 2011. Psikologi Perkembangan : Suatu Pendekatan
Sepanjang Rentang Kehidupan. Jakarta : Erlangga.

Kartikasari, A.D., \&Subandi. 2015. Pelatihan teknik relaksasi untuk menurunkan kecemasan pada primary caregiver penderita kanker payudara. Gadjah Mada Journal of Professional Psychology. Vol.1, No.3.

Kisker, G.W .1997. The disorganized personality: Thirt edition.

McGraw-Hill:Kogakusha,LTD.

Kossek, E. E., \& Ozeki, C. 1999. Bridging the work-family policy an productivity gap: A literature review. Community Work and Family. Vol 2.

Labbé, E., Schmidt, N., Babin, J., \& Pharr, M. 2007. Coping stress the effectiveness of different types music. Journal Apllied Psychophysiology and Biofeedback. Vol 32.

Marks, I., \&Tracssey, 2011. Master your sleep, proven method simplied. USA: Bascom Hills.

Monks, Knoers, R Haditono. 2004. Psikologi Perkembangan Pengantar Dalam berbagai bagiannya. Jogjakarta: Gajah mada University Press.

Resti, B.I (2014). Teknik relaksasi otot progresif untuk mengurangi stres pada penderita asma. Jurnal ilmiah psikologi terapan. Vol.02, No.02

Soewondo, S. 2009. Panduan dan instruksi latihan elaksasi progresif. Depok: Lembaga Pengembangan Sarana Pengukuran dan Pendidikan Psikologi.

Utami, M.S. 2002. Prosedur Relaksasi. Fakultas Psikologi UGM. Yogyakarta. 
110 Jurnal Keterapian Fisik, Volume 4, No 2, November 2019, hlm 59-118

Wijono. 2006. Pengaruh kepribadian tipe

A dan peran terhadap stres kerja manager madya. Journal insan. Vol.8, No.3

Yildirim, Y.K.,2006. The effect of progressive muscle relaxation training on anxiety levels and quality of life in dialysis patient. Journal EDNA/ERLA Vol 22 